„TURYZM", t. 10, z. 2, 2000

Magdalena Małoń

\title{
WALORY TURYSTYCZNE GMINY WOLBÓRZ I ICH WYKORZYSTANIE PRZEZ RUCH TURYSTYCZNY
}

LES VALEURS TOURISTIQUES DE LA COMMUNE DE WOLBÓRZ ET LEUR EXPLOITATION PAR LE MOUVEMENT TOURISTIQUE TOURIST ASSETS OF THE WOLBÓRZ ADMINISTRATIVE DISTRICT AND THEIR USE IN TOURISM

\section{WSTĘP}

Celem autorki pracy było określenie walorów turystycznych gminy, wykazanie ich zróżnicowania przestrzennego. Autorkę interesowało również wykorzystanie walorów turystycznych przez ruch turystyczny oraz zbadanie stopnia znajomości tych walorów przez młodzież szkolną uczącą się na badanym terenie.

Gmina Wolbórz położona jest w woj. łódzkim, w północno-wschodniej części powiatu piotrkowskiego, nad lewym brzegiem Zbiornika Sulejowskiego. Wolbórz jest gminą należąca do Związku Gmin Nadpilicznych. Powierzchnia badanego obszaru wynosi $151 \mathrm{~km}^{2} \mathrm{i}$ w roku 1999 była zamieszkiwana przez 8326 mieszkańców. W skład gminy wchodzą 22 sołectwa i 46 miejscowości.

Siedziba władz gminnych - Wolbórz - jest jedną z najstarszych miejscowości w Polsce. Pierwsze wzmianki historyczne o tej osadzie pochodzą z roku 1065. W XII w. Wolbórz był siedzibą kasztelani w prowincji łęczyckiej. W latach 1136-1148 Bolesław Krzywousty nadał ziemie wolborskie biskupom włocławskim, które były w ich posiadaniu aż do końca XVIII w. Należy zaznaczyć, iż w $1870 \mathrm{r}$. władze rosyjskie odebrały prawa miejskie Wolborzowi i włączyły go do gminy Bogusławice. Pod koniec XIX w. liczba ludności osady wynosiła 3 tys. osób, z czego 700 to mieszkańcy pochodzenia żydowskiego. Narodowość ta od lat dziewięćdziesiątych XIX w. do I wojny światowej stanowiła ponad 
$20 \%$ ogółu mieszkańców Wolborza. W latach trzydziestych XX w. odsetek ten wynosił około $10 \%$. Podczas II wojny światowej przesiedlono Żydów do getta w Piotrkowie Trybunalskim i całkowicie wyniszczono. W okresie tym Wolbórz stał się aktywnym ośrodkiem ruchu oporu. W 1973 r. - w wyniku reformy administracyjnej - utworzono gminę Wolbórz.

W strukturze funkcjonalnej gminy dominuje funkcja rolnicza. Funkcja administracyjna, obsługi ludności i rekreacyjna mają charakter uzupełniający.

Krajobraz badanego terenu jest równinny. Wysokości względne wynoszą ok. $30 \mathrm{~m}$, a bezwzględne od $170 \mathrm{~m}$ n.p.m. do ponad $200 \mathrm{~m}$ n.p.m. Urozmaiceniem krajobrazu są niewysokie wydmy eoliczne w południowej części gminy, które są pokryte lasem. Przez obszar objęty studiami przepływają trzy cieki: Wolbórka, Moszczanka i Goleszanka. Ponadto badany teren leży nad Zbiornikiem Sulejowskim. Szata roślinna obszaru jest charakterystyczna dla Polski środkowej. Lasy zajmują $28 \%$ całego terenu gminy i są skoncentrowane głównie w jej południowej części.

\section{WALORY TURYSTYCZNE I ICH OCENA}

W granicach gminy Wolbórz znajdują się trzy rezerwaty przyrody (dwa leśne $\mathrm{i}$ jeden torfowiskowy), cztery zabytkowe parki podworskie i jeden pałacowy, jeden pomnik przyrody, a ponadto południowa część badanego obszaru leży w granicach Sulejowskiego Parku Krajobrazowego.

Rezerwat Dęby w Meszczach im. Jeremiego Kozłowskiego to rezerwat leśny położony w południowo-zachodniej części gminy. Utworzony został w roku 1989 w celu ochrony starodrzewu dębowego pochodzenia naturalnego, w zespolach o charakterze grądu i boru mieszanego.

Rezerwat Lubiaszów położony w południowej części gminy w pobliżu wsi o tej samej nazwie, tylko fragmentarycznie leży w granicach gminy Wolbórz. Jest to rezerwat leśny. Utworzony został w $1958 \mathrm{r}$. w celu zachowania fragmentu lasu mieszanego z dużym udziałem jodły, która stanowi pozostałość lasu pierwotnego na Wyżynie Lódzkiej, z licznymi roślinami objętymi ochroną gatunkową.

Rezerwat Czarny Lug leży we wschodniej części gminy Wolbórz, w kierunku wschodnim od wsi Młoszów. Ten torfowiskowy rezerwat powołano w roku 1996, aby zachować torfowisko wysokie typu atlantyckiego ze stanowiskiem bagnicy torfowej.

Sulejowski Park Krajobrazowy został utworzony w 1994 r. Jego powierzchnia wynosi 17135 ha. Park znajduje się pomiędzy Spalskim Parkiem Krajobrazowym i Przedborskim Parkiem Krajobrazowym. Od 1995 r. razem z wymienionymi wyżej dwoma parkami krajobrazowymi, wchodzi w skład Zespołu 
Nadpilicznych Parków Krajobrazowych. Sulejowski Park Krajobrazowy zajmuje południową część gminy Wolbórz: sołectwo Swolszewice Duże, Golesze, Lubiaszów oraz lasy żarnowickie i polichnieńskie.

Ponadto w Wolborzu, Bogusławicach, Lubiatowie i Goleszach znajdują się parki zabytkowe. Trzy pierwsze są wpisane do rejestru zabytków (tab. I), a park goleski jest zapisany $w$ ewidencji konserwatorskiej. Prawnie chroniona jako pomnik przyrody jest aleja lipowa w parku przy pałacu biskupów kujawskich w Wolborzu. Aleja składa się z około 100 lip drobnolistnych o obwodzie równym w przybliżeniu $4,5 \mathrm{~m}$.

Badany obszar charakteryzuje zróżnicowanie przestrzenne walorów przyrodniczych; fragment południowy gminy to rezerwaty przyrody i park krajobrazowy, a północna część to przede wszystkim parki podworskie i park pałacowy.

W gminie Wolbórz znajduje się sześć obiektów antropogenicznych wpisanych do rejestru zabytków (tab. I), z czego pięć budynków należy do kompleksu zespołu parkowo-pałacowego biskupów kujawskich w Wolborzu (dwa pawilony, dwie oficyny i pałac), a szóstym jest kościół pod wezwaniem św. Mikołaja w tej samej miejscowości. W ewidencji konserwatorskiej znajdują się 44 pozycje, z czego 43 to obiekty antropogeniczne, a jedna pozycja to park podworski. Poza tym na terenie gminy są cztery pomniki (pomnik Andrzeja Frycza Modrzewskiego, pomnik Czynu Grunwaldzkiego „Dwa Miecze”, Pomnik Czynu Zbrojnego, krzyż upamiętniający Niemców poległych w czasie II wojny światowej), dwa muzea (Muzeum Czynu Partyzanckiego i Izba Pamięci Andrzeja Frycza Modrzewskiego) i 53 przydrożne kapliczki i krzyże, z czego dwa (w Goleszach i w Studziankach) wpisane są do ewidencji konserwatorskiej.

W gminie Wolbórz wyróżnić można następujące formy turystyki specjalistycznej: żeglarstwo, kajakarstwo, wędkarstwo, jeździectwo oraz myślistwo. Ośrodkiem znanym z możliwości uprawiania sportów wodnych jest Bronisławów. Walory jeździeckie skupiają się w Bogusławicach, gdzie znajduje się jedno z 11 istniejących w kraju stado ogierów. Turyści mogą również uprawiać rekreacyjnąjazdę konną w Leonowie.

W pracy została przedstawiona ocena walorów turystycznych gminy Wolbórz metodą bonitacji punktowej. Autorka dokonała oceny walorów krajoznawczych i specjalistycznych korzystając z opracowania J. Wa r s z y ń s k i e j (1971). Na mapie 1:50 000 na terytorium gminy Wolbórz wydzielono kwadraty o powierzchni $1 \mathrm{~km}^{2}$. Następnie dla każdego ze 190 kwadratów obliczono współczynnik atrakcyjności. Kryteria zostały dobrane do obszaru badań według pomyshu autorki i ujęte w czterech grupach:

1. Elementy środowiska w ujęciu krajobrazowo-rekreacyjnym $(\mathrm{N})$ - zastosowana została tutaj czterostopniowa skala; do tej grupy zaliczone zostały trzy elementy: 
Obiekty w rejestrze zabytków w gminie Wolbórz (1999 r.)

Les monuments inserits sur un registre dans la commune de Wolbórz (1999)

\begin{tabular}{|l|l|c|c|c|c|}
\hline \multicolumn{1}{|c|}{ Miejscowość } & Adres & Nazwa & Określenie & Data & Rok rejestru \\
\hline Bogusławice & Bogusławice 23 & park & dworski & pocz. XIX w. & 1983 \\
Lubiatów & & park & dworski & 2 pol. XIX w. & 1983 \\
Wolbórz & ul. Modrzewskiego 107 & park & & 2 poł. XVIII w. & 1967 \\
Wolbórz & ul. Modrzewskiego 107 & pałac & 1773 r. & 1967 \\
Wolbórz & ul. Modrzewskiego 107 & pawilon & 1773 r. & 1967 \\
Wolbórz & ul. Modrzewskiego 107 & pawilon & 1773 r. & 1967 \\
Wolbórz & ul. Modrzewskiego 107 & oficyna & 1773 r. & 1967 \\
Wolbórz & ul. Modrzewskiego 107 & oficyna & & 1773 r. & 1967 \\
Wolbórz & pl. Jagiełly 5 & kościół parafialny rzymsko-katolicki & p.w. św. Mikołaja & XV w. & 1967 \\
\hline
\end{tabular}

Ź r ó d ło: Opracowanie własne na podstawie danych z Wojewódzkiego Oddziału Służby Ochrony Zabytków w Łodzi, Delegatura w Piotrkowie Trybunalskim. 
a) powierzchnia lasów:

$0-9 \%-0$ punktów,

$10-29 \%-1$ punkt,

$30-49 \%-2$ punkty,

powyżej $50 \%-3$ punkty;

b) powierzchnia wód powierzchniowych:

0-9\%-0 punktów,

$10-29 \%-1$ punkt,

$30-49 \%-2$ punkty,

powyżej $50 \%-3$ punkty;

c) rzeźba terenu - różnica wysokości względnej:

0-5 $\mathrm{m}-0$ punktów,

6-10 $\mathrm{m}-1$ punkt,

11-20 $\mathrm{m}-2$ punkty,

powyżej $20 \mathrm{~m}-3$ punkty.

2. Elementy krajoznawcze (K) - antropogeniczne, do których przydzielono dwustopniową punktację - brak obiektu oznacza 0 punktów, a ich istnienie 1,2 lub 3 punkty; zespoły dworskie i pałacowy, których poszczególne obiekty są wpisane do rejestru i ewidencji konserwatorskiej zabytków, zostały wzięte pod uwagę jako pojedyncze obiekty; do elementów tych autorka zaliczyła:

a) obiekty wpisane na listę rejestru zabytków -3 punkty,

b) obiekty wpisane do ewidencji konserwatorskiej - 2 punkty,

c) pomniki-2 punkty,

d) muzea -2 punkty,

e) kapliczki lub krzyże przydrożne - 1 punkt.

3. Elementy specjalistyczne (S), do których zaliczono cztery kategorie:

a) możliwość uprawiania sportów wodnych - wzięto pod uwagę powierzchnię wód-powyżej $10 \%-3$ punkty, poniżej tej wartości - 0 punktów,

b) możliwość uprawiania jeździectwa - 3 punkty,

c) możliwość wędkowania-powierzchnia wód większa niż 10\%-2 punkty, poniżej $9 \%-0$ punktów,

d) możliwość polowania - powierzchnia lasów powyżej 10\% - 2 punkty, poniżej $9 \%-0$ punktów.

4. Punkty dodatkowe $(\mathrm{P})$ przyznane zostały za istnienie:

a) parku krajobrazowego - 1 punkt,

b) rezerwatu przyrody -1 punkt,

c) osobliwości przyrody - zaliczono do nich parki podworskie - 1 punkt.

Po przyznaniu punktów obliczono atrakcyjność turystyczną każdego kwadratu z wzoru:

$$
A=\sum_{i=1}^{n} N_{i}+\sum_{i=1}^{m} K_{i}+\sum_{i=1}^{k} S_{i}+\sum_{i=1}^{j} P_{i}
$$


gdzie:

A - atrakcyjność turystyczna;

$\sum_{i=1}^{n} N_{i}$ - suma elementów środowiska w ujęciu krajobrazowo-rekreacyjnym;

$\sum_{i=1}^{m} K_{i}$ - suma elementów krajoznawczych - antropogenicznych;

$\sum_{i=1}^{k} S_{i}$ - suma elementów specjalistycznych;

$\sum_{i=1}^{i} P_{i}$ - suma punktów dodatkowych.

Zatem atrakcyjność turystyczna oznacza sumę punktów poszczególnych kwadratów, która jest licznikiem we wzorze na współczynnik atrakcyjności turystycznej o postaci:

$$
W_{A}=\frac{A}{\sum_{i=1}^{n} N_{\max i}+\sum_{i=1}^{m} K_{\max i}+\sum_{i=1}^{k} S_{\max i}+\sum_{i=1}^{j} P_{\max i}}
$$

gdzie:

$W_{A}$

- współczynnik atrakcyjności turystycznej;

$\sum_{i=1}^{n} N, \sum_{i=1}^{m} K, \sum_{i=1}^{k} S, \sum_{i=1}^{j} P-$ teoretyczna maksymalna suma punktów odpowiednio:
$N, K, S, P$.

Współczynnik ten przyjmuje wartości od 0 do 1 . W punktacji grupy kategorii przyjmują następujące wartości: $n$-od 1 do $3 ; m$-od 1 do $5 ; k$-od 1 do 4 ; $j-$ od 1 do 3 , zatem teoretyczna maksymalna suma punktów poszczególnych grup cech jest równa odpowiednio:

$$
\sum_{i=1}^{3} n_{\max i}=9, \quad \sum_{i=1}^{5} K_{\max i}=10, \quad \sum_{i=1}^{4} S_{\max i}=10, \quad \sum_{i=1}^{3} P_{\max i}=3,
$$

co po zsumowaniu daje teoretyczną maksymalną sumę punktów wszystkich kategorii: $9+10+10+3=32$.

Po obliczeniu współczynnika atrakcyjności turystycznej wszystkich kwadratów naniesiono na kartogram odpowiednie oznaczenia. Najwięcej kwadratów $52 \%$ całego kartogramu - ma najniższy współczynnik atrakcyjności turystycznej mieszczący się $w$ granicach $0-0,12$. Aż $35 \%$ to tereny o badanym współ- 
czynniku od 0,13 do 0,24 . Nieco mniej kwadratów osiagnęło wartości od 0,25 do 0,37 i są one zgrupowane przede wszystkim wokół Zalewu Sulejowskiego. Tylko 4\% łącznie stanowią obszary o współczynniku mieszczącym się w przedziale 0,38-0,74. Rozpatrując tę grupę zauważyć można, iż największy współczynnik atrakcyjności osiągnęły kwadraty pokrywające Wolbórz oraz południową część Bogusławic - od 0,38 do 0,66 - na co wpłynęły walory antropogeniczne. Dużą wartość badanego współczynnika mają tereny w południowo-wschodnim fragmencie gminy, czyli nad Zbiornikiem Sulejowskim - od 0,25 do 0,47 . Są to obszary grupujące walory przyrodnicze, specjalistyczne oraz wypoczynkowe.

W następnej kolejności obliczono średnią arytmetyczną otrzymując w ten sposób współczynnik atrakcyjności całej gminy Wolbórz:

$$
\frac{\sum_{i=1}^{190} W_{A}}{190}=\frac{26,48}{190}=0,14
$$

Według klasyfikacji J. W a r s z y ń s k i e j (1971) gmina ta w skali kraju należy do obszarów o małej atrakcyjności turystycznej.

Badany obszar - w powszechnym mniemaniu - nie jest położony w atrakcyjnym turystycznie obszarze Polski. Część środkowa naszego kraju to obszar płaski, monotonny, poprzecinany ciekami i sztucznymi jeziorami, o małej lesistości. Gmina Wolbórz posiada dostęp do jeziora, prawie 1/3 powierzchni zajmują lasy, znajdują się tutaj walory dokumentujące przeszłość, a zatem wyróżnia się na tle innych gmin leżących w pobliżu aglomeracji łódzkiej. Według autorki walorami, które przyciągaja ruch turystyczny na badany obszar jest Zbiornik Sulejowski, Stado Ogierów w Bogusławicach oraz, w mniejszym stopniu, zespół parkowo-pałacowy biskupów kujawskich w Wolborzu.

\section{RUCH TURYSTYCZNY}

Wielkość ruchu turystycznego autorka oceniła na podstawie danych z obiektów noclegowych na terenie gminy Wolbórz. Ogólem z noclegów w tych obiektach w roku 1999 skorzystało 2478 osób. Strukturę noclegów z uwzględnieniem poszczególnych obiektów przedstawia tab. II.

W celu scharakteryzowania ruchu turystycznego autorka posłużyła się analizą ankiet przeprowadzonych na terenie gminy Wolbórz. Próba stanowiła $8 \%$ ogólu turystów, którzy przybyli na obszar gminy w 1999 r., czyli 192 respondentów. 
Położenie gminy Wolbórz nad Zalewem Sulejowskim oraz walory przyrodnicze, głównie lasy, przesądzają o tym, że ruch turystyczny ma charakter sezo-

T a be I a II

Korzystający z noclegów w gminie Wolbórz wg obiektów noclegowych (1999 r.)

Les personnes ayant profité de base de couchage dans la commune de Wolbórz (données des objets de couchage) 1999

\begin{tabular}{|l|c|c|}
\hline \multirow{2}{*}{ Obiekt noclegowy } & \multicolumn{2}{|c|}{ Osoby korzystające z noclegów } \\
\cline { 2 - 3 } & liczba & $\%$ \\
\hline Ośrodek Wypoczynkowy & 1014 & 41,0 \\
,Wodnik" & 800 & 32,0 \\
\hline Internat przy Zespole Szkól & & 14,0 \\
RCKU & 340 & 11,0 \\
\hline Autokemping w Leonowie & 272 & 2,0 \\
\hline Pensjonat w Boguslawicach & 52 & 0,0 \\
\hline Gospodarstwa agroturystyczne & 0 & 0,0 \\
w tym: & 0 & 0,0 \\
Boguslawice 6 & 0 & 0,5 \\
Bogusławice 17 & 14 & 1,0 \\
Boguslawice 25 & 26 & 0,5 \\
Leonów & 12 & 100,00 \\
Proszenic & 2478 & \\
Wolbórz & & \\
\hline Suma & & \\
\hline
\end{tabular}

Ź r ó d l o: Opracowanie własne na podstawie danych z obiektów noclegowych.

nowy. Jedynie wędkarze, myśliwi, turyści uprawiający jazdę konno oraz osoby, dla których celem lub etapem przyjazdu na obszar gminy są walory antropogeniczne, przybywają na badany obszar w ciągu calego roku. Sezonowość ruchu turystycznego autorka oceniła na podstawie danych z obiektów noclegowych i badań ankietowych. Wskaźnik sezonowości dla poszczególnych miesięcy obliczono korzystając ze wzoru (M a t c z a k 1998):

$$
W_{S}=\left(L_{t m} L_{\text {sr } r}\right) \times 100
$$

gdzie:

$L_{t m}$ - liczba turystów w kolejnym miesiącu,

$L_{\text {sr } t}-$ średnia miesięczna liczba turystów w ciągu roku, która wynosi 206,5. 
Wskaźnik ten jest ujęty w tab. III.

Podobne wyniki dały badania ankietowe. Na pytanie „W jakiej porze roku miały miejsce poprzednie wizyty?" 83 respondentów odpowiedziało, że latem, dwoje - jesień. Biorąc pod uwagę łączne odpowiedzi, lato zaznaczyło 127 ankietowanych.

\section{T a b e 1 a III}

Korzystający z noclegów w gminie Wolbórz wg miesięcy i wskaźnik sezonowości (1999 r.)

Les personnes ayant profité de base de couchage dans la commune de Wolbórz selon les mois et l'indice du caractère saisonnier de la localité

\begin{tabular}{|l|c|c|}
\hline \multicolumn{1}{|c|}{ Mieșiąc } & Liczba osób & Wskaźnik sezonowości (\%) \\
\hline Styczeń & 10 & 4,8 \\
Luty & 33 & 16,0 \\
Marzec & 36 & 17,4 \\
Kwiecień & 9 & 4,4 \\
Maj & 310 & 150,1 \\
Czerwiec & 324 & 156,9 \\
Lipiec & 700 & 339,0 \\
Sierpień & 795 & 385,0 \\
Wrzesień & 169 & 81,8 \\
Październik & 34 & 16,5 \\
Listopad & 33 & 16,0 \\
Grudzień & 25 & 12,1 \\
\hline
\end{tabular}

Ź ró d l o: Opracowanie wlasne na podstawie danych z obiektów noclegowych.

W gminie Wolbórz dominuje zarówno ruch turystyczny długookresowy, jak i krótkookresowy (rys. 1). Średnia długość pobytu wynosi $10 \mathrm{dni}$.

Kolejnym kryterium podziału ruchu turystycznego jest motyw oraz cel wyjazdu. Z badań wynika, że motywy przyjazdu, charakter pobytu i sposób spędzania wolnego czasu zależą od walorów turystycznych miejscowości, w której prowadzone są badania, cech społecznych, wieku uczestników ruchu turystycznego i innych czynników.

Turyści podawali różne motywy przyjazdu do gminy Wolbórz. Najczęściej zaznaczanymi odpowiedziami były: chęć wypoczynku (131 osób), walory turystyczne obszaru (125) i bliskość miejsca zamieszkania (103). Najmniej osób przyjechało do miejscowości położonych w gminie Wolbórz, aby odwiedzić krewnych lub znajomych, na wycieczkę i przez przypadek (od czterech do 10 odpowiedzi). Chęć uprawiania sportu zaznaczyło 74 respondentów. Były to głównie osoby ankietowane w miejscowościach nad Zalewem Suejowskim oraz w Bogusławicach. 
Motyw ten wynika $\mathrm{z}$ istnienia portu jachtowego w Bronisławowie i Stada Ogierów w Bogusławicach. 39 ankietowanych zaznaczyło też wariant „inny”. Byli to uczestnicy rekolekcji ignacjańskich, którzy przyjechali do Wolborza, aby uczestniczyć w modlitwach i medytacjach. Dla pozostałych osób, które m.in. zaznaczyły ten wariant, motywem przyjazdu była chęć uprawiania hobby myślistwa, wędkarstwa bądź grzybobrania.

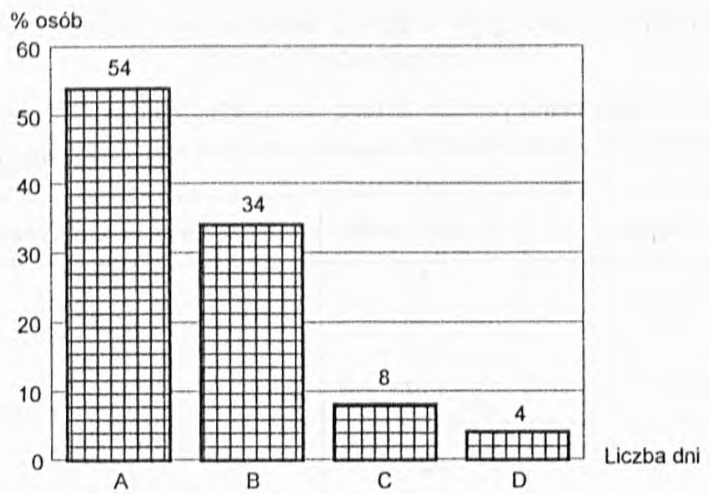

Rys. 1. Długość pobytu respondentów w gminie Wolbórz (badania z sierpnia $1999 \mathrm{r}$.)

A - 1-7 dni, B - 8-14 dni, C - 15-21 dni, D - 22 dni i więcej

Dessin 1. La longueur du séjour des touristes enquêtés dans la commune de Wolbórz (recherches faites en août 1999)

$A-1-7$ jours, $B-8-14$ jours, $C-15-21$ jours, $D-22$ jours et plus

Biorąc pod uwagę charakter pobytu w danej miejscowości, to najwięcej osób zaznaczyło wczasy - 106. Tylko po jednym lub po dwóch respondentów zadeklarowało, że pobyt miał charakter rajdu, był to tranzyt, czy pobyt na działce ewentualnie u rodziny.

Motywy przyjazdu oraz charakter pobytu wiążą się ze sposobem spędzania wolnego czasu. Nie można jednak wyodrębnić jednolitego schematu, ponieważ turyści spędzali czas zarówno w sposób bierny, jak i czynny, np. uprawiając sporty wodne, czy wycieczki piesze. Najwięcej osób zadeklarowało, że będzie spędzać czas biernie - 127 odpowiedzi. Na drugim miejscu zaznaczano sporty wodne -79 , następnie wycieczki piesze - 54 i jeździectwo -45 . Wycieczki rowerowe zaznaczyło tylko 23 respondentów. Wśród 72 ankietowanych, którzy udzielili również odpowiedzi innej niż sugerowano w ankiecie, najczęściej pojawiały się następujące sposoby spędzania wolnego czasu na terenie gminy Wolbórz: wędkowanie, ogniska, spotkania towarzyskie, grzybobranie, medytacje i modlitwy, spacery i polowania. 
Spośród 192 ankietowanych 48\% stanowiły kobiety. Dominujący udział uczestników ruchu turystycznego na terenie gminy Wolbórz w 1999 r. mieli ludzie młodzi. 19\% ogółu respondentów reprezentowało grupę wiekową do 19 lat. Najwięcej ankietowanych, bo aż 39\% mieściło się w przedziale wiekowym od 20 do 29 lat. Po kilka procent respondentów zanotowano w przedziałach wiekowych 50-59, 60-69 i 70-79 lat. Wśród młodzieży, trzydziestolatków oraz siedemdziesięciolatków przeważały kobiety (rys. 2). W pozostałych grupach mężczyźni.
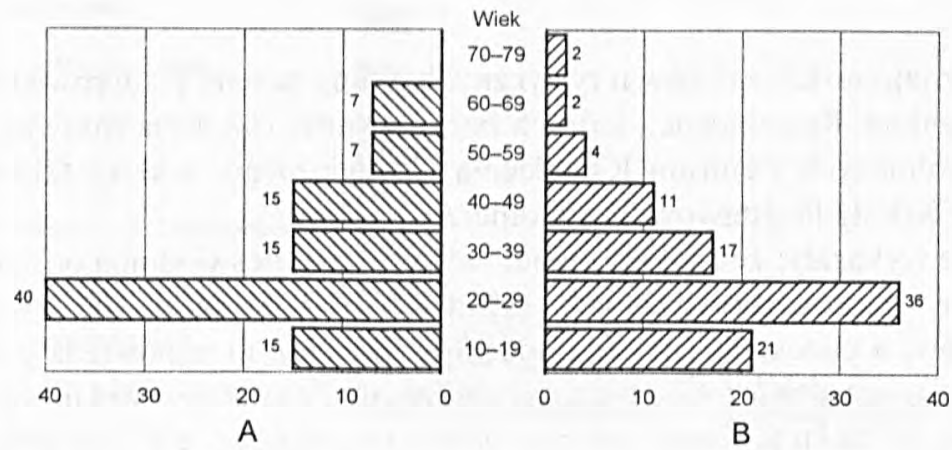

Rys. 2. Struktura wieku i płci ankietowanych turystów w gminie Wolbórz (sierpień 1999) A - mężczyźni, B - kobiety

Dessin 2. La structure de l'âge et du sexe des touristes enquêtés dans la commune de Wolbórz (août 1999)

A - hommes, B - femmes

Biorąc pod uwagę kryterium wykształcenia, to w każdej grupie wiekowej powyżej 20 lat dominowało wykształcenie średnie.

Gros uczestników ruchu turystycznego w Wolborzu i okolicach to mieszkańcy aglomeracji tódzkiej - $80 \%$ respondentów. $Z$ tego $56 \%$ turystów to mieszkańcy Łodzi i okolic w promieniu ok. $20 \mathrm{~km}$. Walory turystyczne gminy Wolbórz przyciagają również mieszkańców Górnego Śląska. Z konurbacji tej oraz całego województwa śląskiego pochodzi $9 \%$ ankietowanych. Pozostali respondenci (do kilku procent) to mieszkańcy województw: dolnośląskiego, kujawsko-pomorskiego, mazowieckiego, opolskiego, pomorskiego, warmińsko-mazurskiego i wielkopolskiego.

Ogółem ruch turystyczny na terenie gminy Wolbórz ma charakter sezonowy. Zauważa się przyjazdy zarówno długookresowe (urlopowe), jak i krótkookresowe (wypoczynek świąteczny), co potwierdziły badania ankietowe oraz inwentaryzacja obiektów noclegowych. 
Z powyższej analizy wynika również, że na obszarze objętym studiami występują wszystkie trzy typy ruchu turystycznego wydzielone przez J. W a r s z y ń s ką i A. J a c k o w s k i e g o (1979). Turyści uprawiają zarówno turystykę wypoczynkową (pobytową), jak i krajoznawczą oraz specjalistyczna, taką jak żeglarstwo, wędkarstwo, myślistwo i jeździectwo. Zasięg turystyczny wskazuje na lokalne znaczenie gminy Wolbórz.

\section{OCENA ZNAJOMOŚCI WALORÓW TURYSTYCZNYCH GMINY WOLBÓRZ PRZEZ MLODZIEŻ SZKOLNA}

Ocena znajomości walorów turystycznych gminy została przeprowadzona na podstawie ankiet. Respondenci, których liczba wynosi 168, to uczniowie Zespołu Szkół Rolniczych Centrum Kształcenia Ustawicznego, I klasy Gimnazjum i VIII klasy Szkoły Podstawowej w Wolborzu.

Badania wykazały, że aż 39\% ankietowanych jest nieświadoma posiadanych przez gminę walorów turystycznych. 19\% twierdziło, że gmina nie posiada takich walorów, a pozostałe $42 \%$ respondentów zaznaczyło odpowiedź pozytywną. Większą wiedzą wykazali się uczniowie Szkoły Podstawowej i Gimnazjum $52 \%$ uważa, że badany obszar posiada walory turystyczne, a $8 \%$ twierdziło, że nie. W przypadku słuchaczy Zespołu Szkół Rolniczych Centrum Kształcenia Ustawicznego $34 \%$ zaznaczyło odpowiedź twierdząca, a $27 \%$ przeczącą. Po $39 \%$ respondentów z każdej grupy nie wie, czy gmina posiada walory turystyczne. Rysunek 3 ilustruje, jakie walory wymieniali uczniowie. Najwięcej ankietowanych wskazało na zespół parkowo-pałacowy biskupów kujawskich w Wolborzu. Na następnym miejscu znajduje się Stado Ogierów w Bogusławicach, a ponadto $11 \%$ respondentów z Gimnazjum i Szkoły Podstawowej w Wolborzu wymieniło walory wypoczynkowe. Po około 5\% uczniów wymieniło Zalew Sulejowski, pomnik Andrzeja Frycza Modrzewskiego i kościół św. Mikolaja.

Żaden uczeń poprawnie nie wymienił nazw miejscowości, przez które przebiega Szlak Partyzancki Małego Franka, a $88 \%$ ankietowanych wprost zaznaczyło, że nie wie przez jakie miejscowości przebiega wymieniony szlak turystyczny.

Wolbórz uczniowie kojarzą ze szkołą, zespołem parkowo-pałacowym, bitwą pod Grunwaldem, kościołem św. Mikołaja oraz miejscem zamieszkania. Polichno natomiast $\mathrm{z}$ muzeum, motelem i pomnikiem Czynu Zbrojnego, Bronisławów z Zalewem Sulejowskim, wypoczynkiem, wycieczkami, a Bogusławice ze stadem ogierów.

Prawie wszyscy uczniowie, którzy wypełnili ankiety, byli w wymienionych wyżej miejscowościach. Motywami były: w przypadku Wolborza uczęszczanie 
do szkoły, Polichna - przypadek, Bronisławowa - walory turystyczne miejscowości, a w przypadku Bogusławic - chęć uprawiania sportu.
1. walory Polichna
2. walory wypoczynkowe
3. pomnik Czynu Grunwaldzkiego
4. krajobraz
5. szata leśna
6. kaplica św. Rocha
7. kaplica św. Anny
8. Zalew Sulejowski
9. pomnik A. F. Modrzewskiego
10. kościół św. Mikołaja
11. stadnina ogierów
12. zespół parkowo-pałacowy

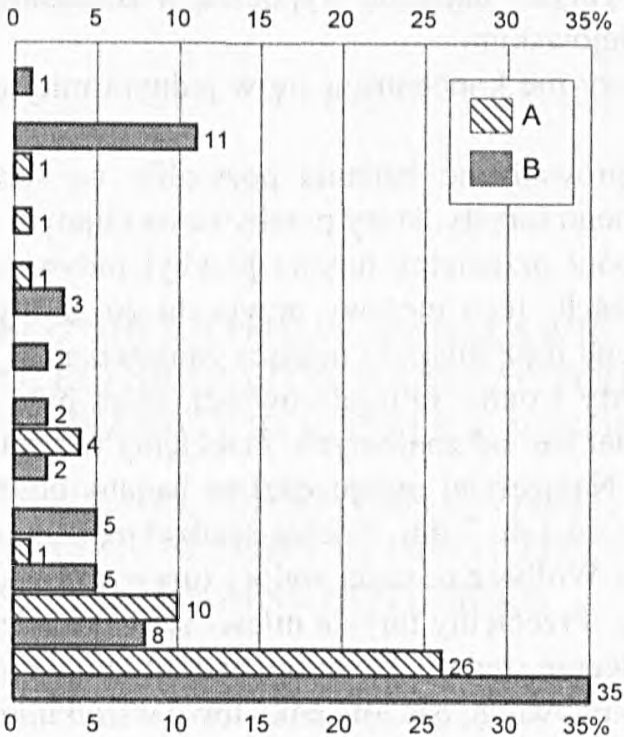

Rys. 3. Walory turystyczne gminy Wolbórz w opinii uczniów

1 - walory Polichna, 2 - walory wypoczynkowe, 3 - pomnik Czynu Grunwaldzkiego, 4 - krajobraz, 5 - szata leśna, 6 - kaplica św. Rocha, 7 - kaplica św. Anny, 8 - Zalew Sulejowski, 9-pomnik A. F. Modrzewskiego, 10 - kościól św. Mikolaja, 11 -stadnina ogierów, 12 -zespól parkowo-palacowy; A - Gimnazjum i Szkoła Podstawowa w Wolborzu (GiSP), B - Zespół Szkól Rolnicze Centrum Ksztalcenia Ustawicznego (ZSRCKU)

Rys. 3. Les valeurs touristiques de la commune de Wolbórz évaluées par les écoliers 1 - les valeurs de Polichno, 2 - les valeurs de repos, 3 - le monument de l'Acte de Grunwald, 4 - le paysage, 5 - le tapis végétal, 6 - la chapelle St. Roch, 7 - la chapelle St. Anne, 8 - la submersion de Sulejów 9- le monument de A. F. Modrzewski, 10 - l'église St. Nicolas, 11 - le haras des étalons, 12 - l'ensemble - parc et palais; A - le Gymnase et l'Ecole Primaire à Wolbórz,

B - l'Ensemble des Ecoles Agricoles, Centre de l'Education Incessante

\section{WNIOSKI}

Podsumowując należy stwierdzić, że na badanym obszarze turysta znajdzie wszystkie rodzaje walorów turystycznych: krajoznawcze, specjali poczynkowe. $Z$ walorów krajoznawczych przyrodniczych najcenniejsze są rezerwaty przyrody. Południowa część gminy Wolbórz leży w granicach terenu, który jest chroniony ze względu na wartości przyrodnicze, historyczne oraz kulturowe, czyli Sulejowskiego Parku Krajobrazowego. Walory krajoznawcze an- 
tropogeniczne przypominają o przeszłości historycznej zarówno badanego obszaru, jak i całej Polski. Formy turystyki kwalifikowanej można uprawiać wykorzystując walory specjalistyczne, które dominują w Bronisławowie i Bogusławicach. Turyści najlepiej wypoczną w Bronisławowie i w Leonowie nad Zalewem Sulejowskim.

Walory nie koncentrują się w jednym miejscu, ale są rozproszone po całej gminie.

Przeprowadzone badania pozwoliły na skonstruowanie ogólnej sylwetki przeciętnego turysty, który przebywa na objętym studiami terenie. Na teren gminy Wolbórz przeciętny turysta przybył indywidualnie, własnym samochodem, na wczasach. Jego motywy przyjazdu do gminy to chęć wypoczynku, walory turystyczne oraz bliskość miejsca zamieszkania. Spędzał czas biernie lub uprawiał sporty wodne. O miejscowości, która była jego głównym celem podróży, dowiedział się od znajomych. Przeciętny turysta przybył na teren gminy po raz kolejny. Najczęściej przyjeżdżał na badany obszar latem. Długość jego pobytu wynosiła od 1 do 7 dni. Nocleg spędzał na kempingu w Bronisławowie. Uważa, że gmina Wolbórz posiada walory turystyczne, którymi są wody powierzchniowe i lasy. Przeciętny turysta mieści się w przedziale wiekowym 20-29 lat i ma wykształcenie średnie. Uczy się, bądź studiuje i mieszka w Lodzi.

Podsumowując badania ankietowe wśród młodzieży szkolnej należy zwrócić uwagę na fakt, że przeciętny uczeń nie wie, czy gmina Wolbórz posiada walory turystyczne i nie wie, przez jakie miejscowości przebiega Szlak Partyzancki Małego Franka. Wolbórz kojarzy najczęściej ze szkołą lub zespołem parkowo-pałacowym biskupów kujawskich, Polichno z motelem, Bronisławów z Zalewem Sulejowskim, a Bogusławice ze Stadem Ogierów. Uczeń był we wszystkich czterech wymienionych wyżej miejscowościach. Długość pobytu wynosiła jeden dzień.

Gmina Wolbórz to prężnie rozwijający się obszar, a zatem ma duże szanse, aby uzyskać rangę krajową oraz wpłynąć na zwiększenie ruchu turystycznego, z czym związany jest również rozwój ekonomiczny gminy.

\section{PIŚMIENNICTWO}

M a t c z a k A., 1998, Turystyczna baza noclegowa Lodzi i jej wykorzystanie $w$ latach 19791999, „Turyzm”, t. 8, z. 2.

Materialy do dziejów rezydencji w Polsce. Woj. sieradzkie, T. I, Puget W. (red.), 1990, Stowarzyszenie Historyków Sztuki Instytutu Sztuki PAN, Warszawa.

Warszyńska J., 1971, Waloryzacja miejscowości z punktu widzenia atrakcyjności turystycznej, Zeszyty Naukowe UJ, Prace Geograficzne, z. 27.

W a r s z y ń s k a J., J a c k o w s k i A., 1979, Podstawy geografii turyzmuı, PWN, Warszawa. 